\title{
DAMAGE TO EARTH STRUCTURES AND FOUNDATIONS BY THE NIIGATA EARTHQUAKE JUNE 16, 1964, IN JNR.
}

\author{
Goji, Yamada*.
}

\section{INTRODUCTION}

On June 16, 1964 a great earthquake occurred at Niigata Prefecture, Japan. A map of damaged area is shown in Fig. 1, and a general scope of damage to railway facilities is shown in Table 1.

The area seriously damaged by the earthquake is fairy restricted to the narrow area in neighbourhood of the mouth of the Shinano River and the degree of damage has close relation to soil foundation and properties.

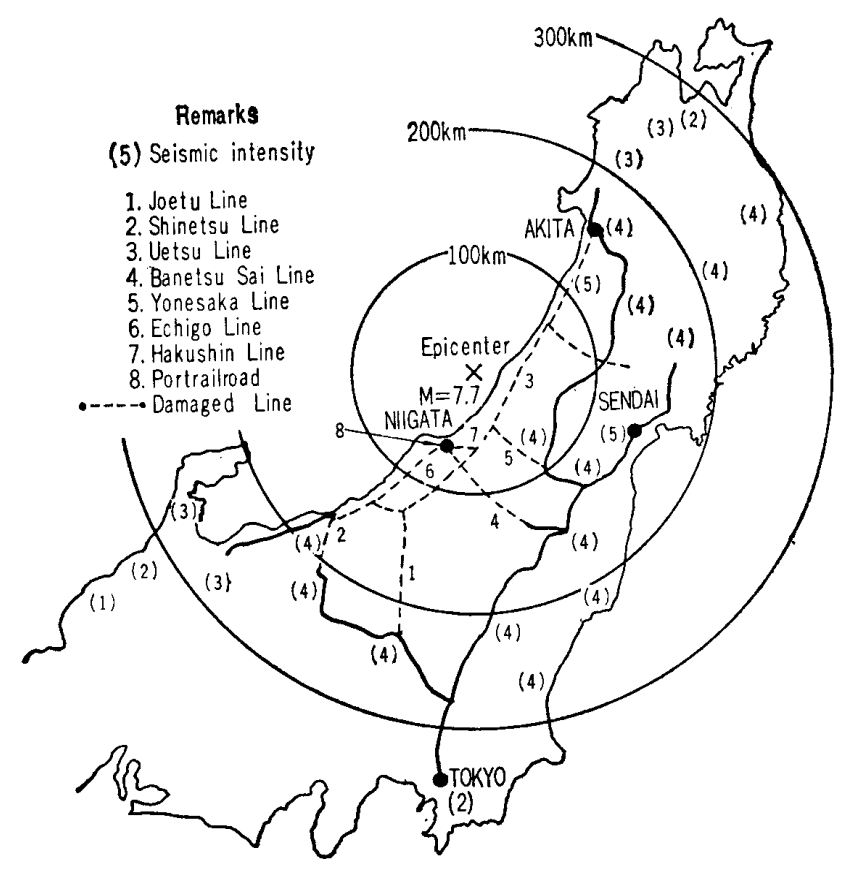

Fig. 1. Map of damage area in JNR

Soil formation of this area consists chiefly of recent alluvial deposit and recently deposited artificial fill which are composed of relatively uniform, loose and saturated sand.

The vibration due to earthquake induced the liquefaction of saturated loose sand and caused much damage to earth structure and foundation. The railway fill which ran over the damaged area settled exclusively and in some case completely failed or slumped and the movement of abutment and rotation of bridge pier with well founda-

- Railway Technical Research Institute, JNR. 
Table 1. Damge to railway facilities. Niigata Eathquake.

\begin{tabular}{|c|c|c|c|c|c|c|c|c|c|}
\hline Damage Line & Jo-etsu & $\begin{array}{l}\text { Shin- } \\
\text { etsu }\end{array}$ & Uetsu & $\begin{array}{l}\text { Ban- } \\
\text { etsu }\end{array}$ & Yonesaka & Hakushin & Echigo & $\begin{array}{l}\text { Port- } \\
\text { railroad }\end{array}$ & Total \\
\hline $\begin{array}{l}\text { Settlement of } \\
\text { Roadbed }\end{array}$ & 5 & 18 & 34 & 4 & 6 & 1 & 23 & whole & 91 \\
\hline $\begin{array}{c}\text { Disorder of } \\
\text { Track }\end{array}$ & & 1 & 19 & & 1 & 2 & 17 & & 40 \\
\hline Earth Collapse & & & 8 & 1 & & & & & 9 \\
\hline Rock fall & & & 4 & & & & & & 4 \\
\hline Crack of Fill & 1 & 1 & 9 & 1 & 1 & 1 & 4 & & 18 \\
\hline $\begin{array}{l}\text { Tipping of } \\
\text { Abutment and Pier }\end{array}$ & & 3 & 19 & 3 & 3 & 1 & 10 & & 39 \\
\hline Fall of Girder & & 1 & & & & & & & 1 \\
\hline $\begin{array}{c}\text { Detormation of } \\
\text { Tunnel }\end{array}$ & 2 & 2 & 9 & & 1 & & 2 & & 16 \\
\hline $\begin{array}{l}\text { Detorimation of } \\
\text { Platform }\end{array}$ & 1 & & 2 & & & & & & 3 \\
\hline Total & 9 & 26 & 104 & 9 & 12 & 5 & 56 & 一 & 221 \\
\hline
\end{tabular}

tion were experienced.

Other major damage was slope failure which occurred along Uetsu-Line at mountain area near the epicentre.

No severe damage to tunnel was discovered except few tunnels locating beneath a slope having landslide feature.

Concerning railway facilities it is noted that damage in other districts is slight in spite of similar earthquake scale.

In this report observation of damage and field investigation of earth-structure and foundation are chiefly presented.

\section{OBSERVATION AND SITE INVESTIGATION OF DAMAGE}

(1) Slumping and settlement of railway fills

A characteristic damage due to the Niigata earthquake concentrated in places with poor subsurface condition. On the contrary a good soil condition resulted in slight damage.

Echigo-Line which runs along the left side of the Shinano River suffered the settlement of roadbed and disorder of track all along a line. However, the section between Sekiya St. and Hakusan St. suffered serious damage by the earthquake. This 
area had been located at a previously meandering site of the Shinano River several centuries ago and after that it was built by successive deposition of sand. As the railway fill was built near the boundary between new and old deposition, a dagage to the fill had a tendency to be progressively worse towards river and was related to the subsurface condition.

Fig. 2 shows damaged area in the vicinity of Niigata City. Railway fill having 5 to 6 meters height collapsed completely.

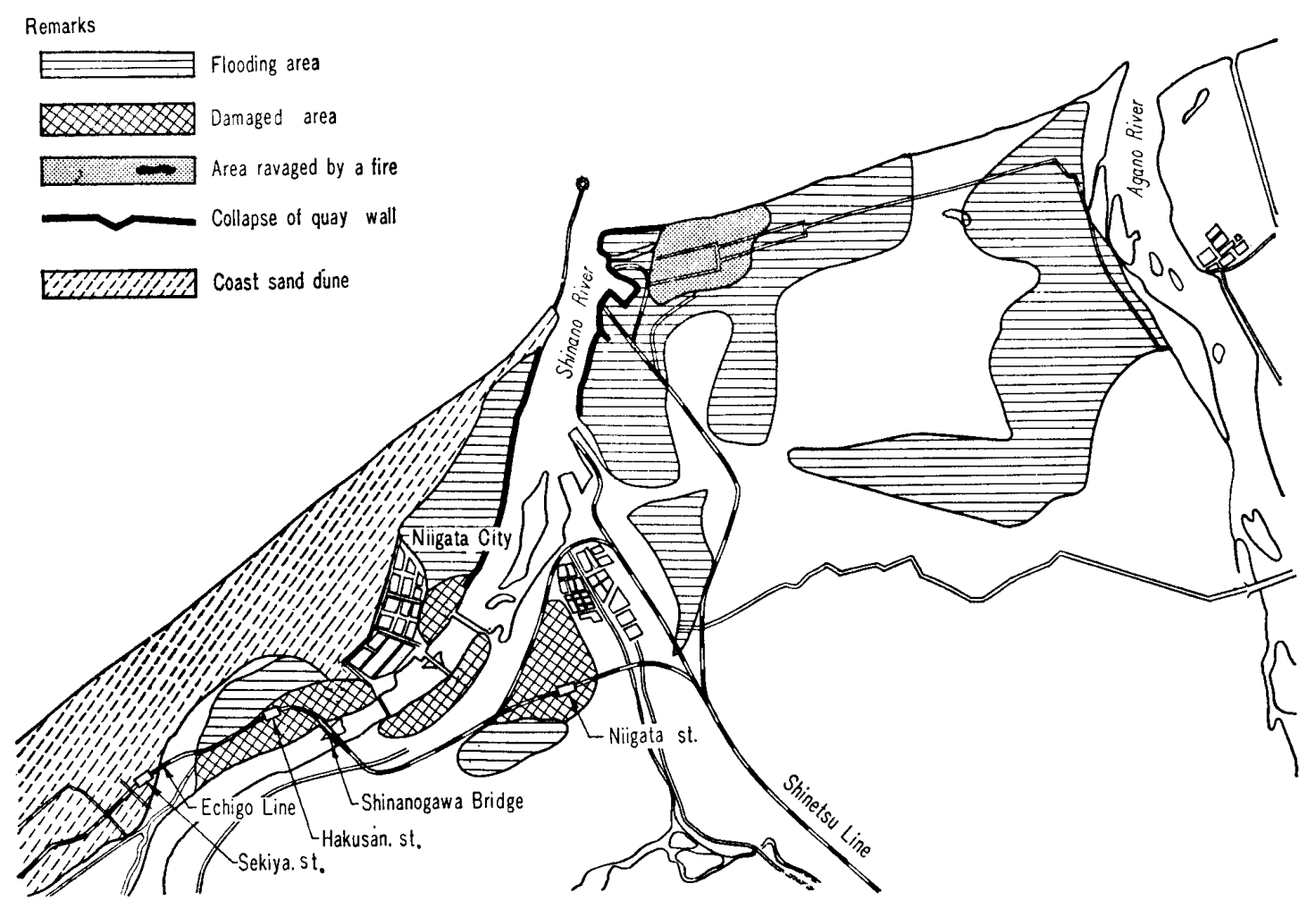

Fig. 2. Damaged area in the vicinity of Niigata-city

It is characteristic that the portion of roadbed slumped down by about 2 or 3 meters into soft ground while the portion of slope remained almost original state. The slumping of fill is shown in Fig. 3 and Photos. 1, 2, 3.

Settlement of fill forming bridge approach was very widely observed. The riverside road parallel to railway fill upheaved slightly. Several longitudinal fissures with mud-pumping and sand boils with throat diameter were observed.

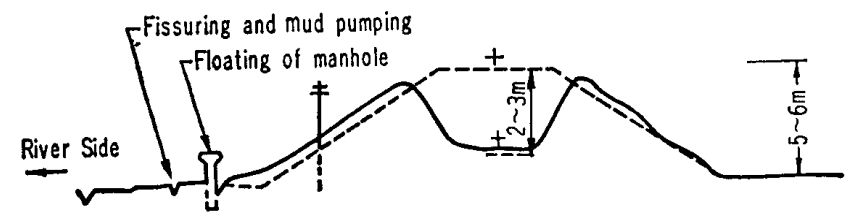

Fig. 3. Slumping of fill (Echigo Line) 


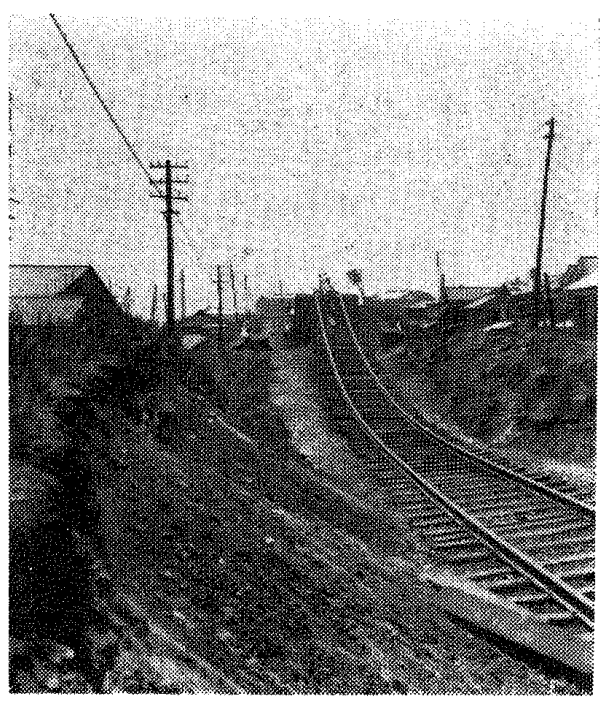

Photo. 1. Slumping of fill near Teramae Bridge

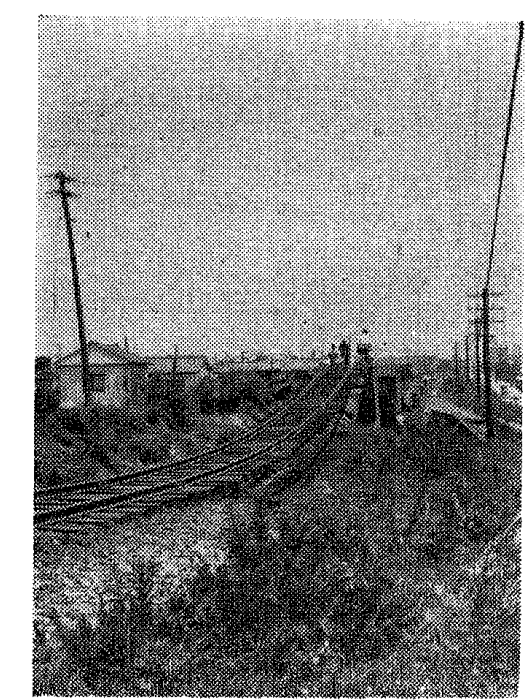

Photo. 2. Slumped a pproach fill near Teramae Bridge

Manholes buried underground rose to the surface. The soil formation of this area consists of loose saturated sand having $N$ value of less than 4 up to 5 meters depth below the ground surface. Slumping of the heavy weight structure such as fill, floating of the light weight structure such as manhole, fissures with mud-pumping and sand boils,- these phenomena are evidence of liquefaction of subsurface deposits and similar phenomena have been reported at other sections of Niigata City. (2) Flow slide of high fill due to liquefaction

The fill located between Dedo St. and Nishime St. in Uetsu-Line was built on flat and shallow valley between sand hills. The fill of about 7 meters height collapsed at one direction over a length of 150 meters and the sliding mass, mixture of sand and water, flowed over the ground surface up to 110 meters distance from a centre of track. 


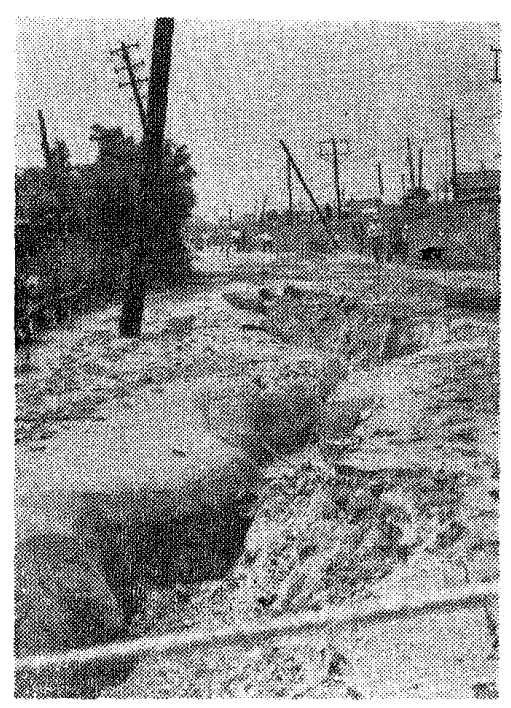

Photo. 3. Fissuring and mud pumping on road

The widespreading failure of fill are caused by liquefaction of fill material due to vibration of earthquake.

A farmer who worked near the fill at a time of the earthquake recognized that the middle part of slope broke out initially and flowed over the ground surface at relatively high speed. The upper part of roadbed with ballast fell down vertically and track became like a ladder. It is recognized that only fill itself flow-slided, because the ground surface at both sides and below fill had no mark of sliding.

Grain size distribution curves of fill material, slided soil and material from borrow pit are shown in Fig. 4. As these curves coincide closely with each other, a separation of grains due to liquefaction can not be recognized.

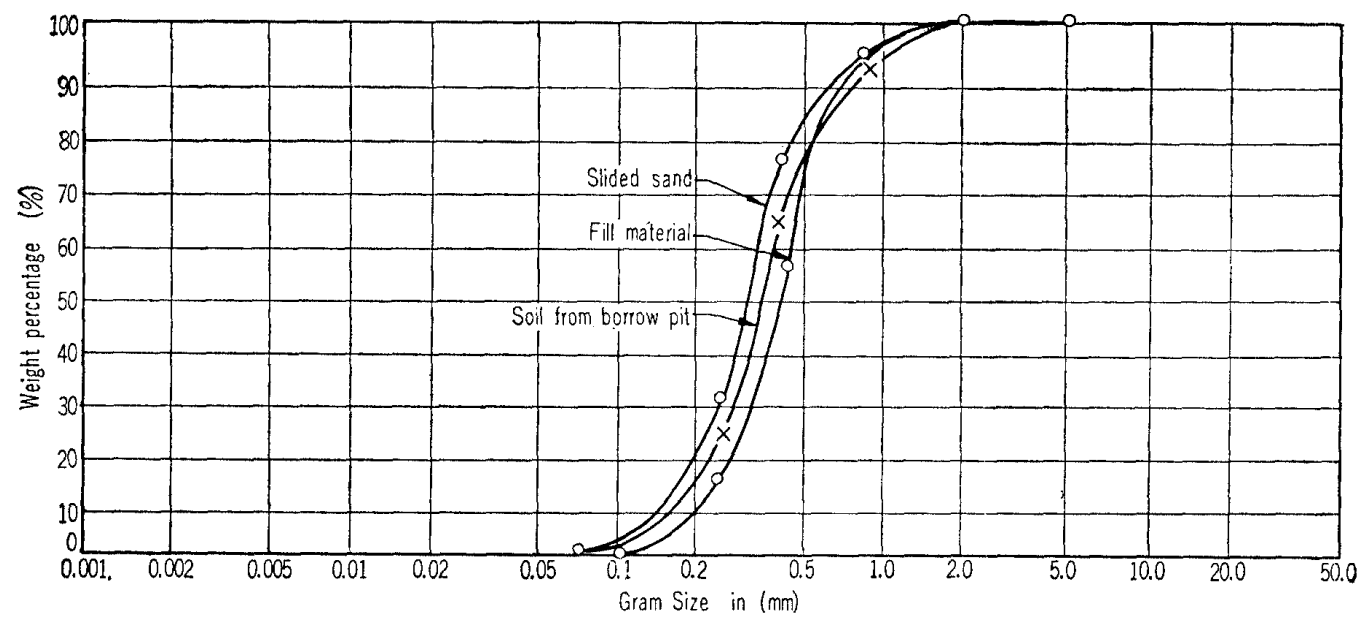

\begin{tabular}{|l|l|l|l|l|}
\hline & Clay & Sit & Sand & Gravel \\
\hline
\end{tabular}

Fig. 4. Comparison of grain size distribution curves 


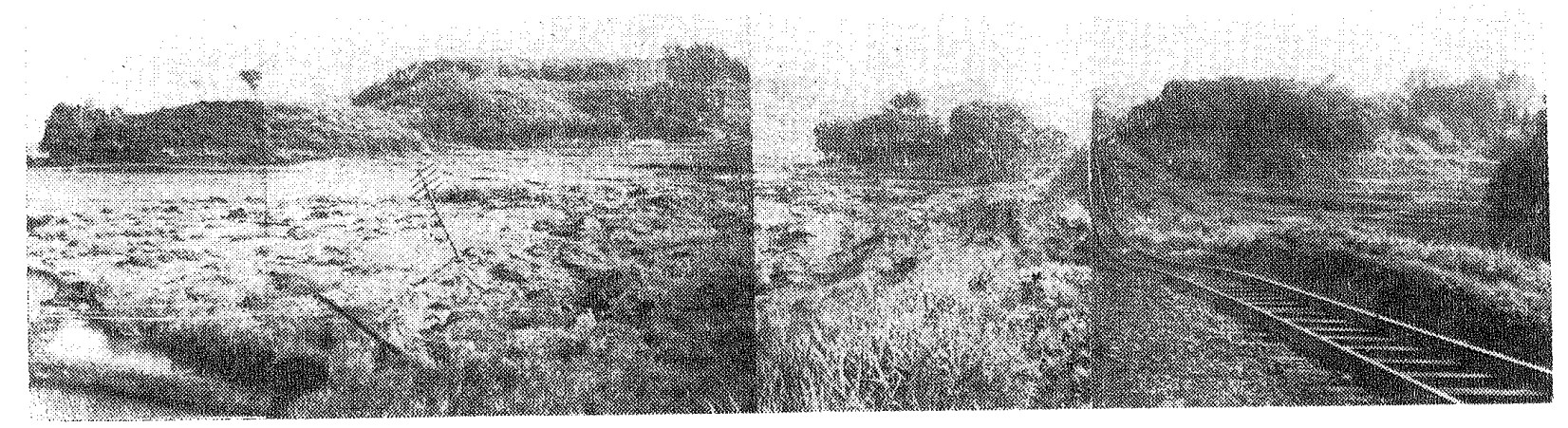

Photo. 4. Flow slide of railway fill due to lequefaction of fill material between Dedo st. and Nishime st. in Uetsu Line

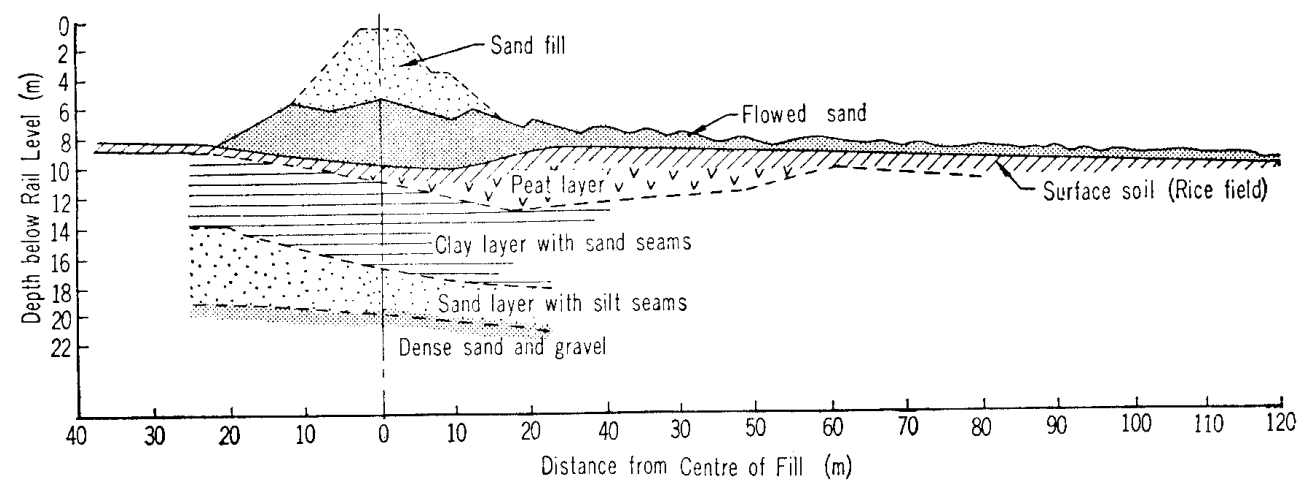

Fig. 5. Cross section of failed fill of Uetsu-Line

Photo. 4 shows a general view of fill failure and Fig. 5 shows the cross section after failure.

As shown in Fig. 5, soil formation of natural ground consists of silt layer containing sand seams and sand layer containing silt seams. At the ground surface below fill there are peat layer of about 3 meters thickness and this portion may be a site of swamps. The peat layer below fill contributed to the accumulation of water according to the settlement in itself, and lower part of fill was saturated with water.

This instructive failure of an artificial fill is due to liquefaction of loose saturated sand and contribution of displacement of peat layer caused by earthquake shock.

(3) Collapse of natural and cut slope

Several slope failures and rock-falls occurred in the vicinity of epicentral area where Uetsu-Line runs along a coastal line near a foot of mountain. In this area a collapse of slope had been feared in rainy seasons. However there were few slope failures caused by the earthquake, though visible surface cracks of slope occurred in many places.

After earthquake this area was caught in heavy rain, and total amount of rainfall reached to $500 \mathrm{~mm}$ from July 3 to July 19 . This heavy rain induced a great number of slope failures under influence of cracks caused by the earthquake. The influence of earthquake, such as fissures and cracks, will remain as the future problem of preventive measure of slope failure. 


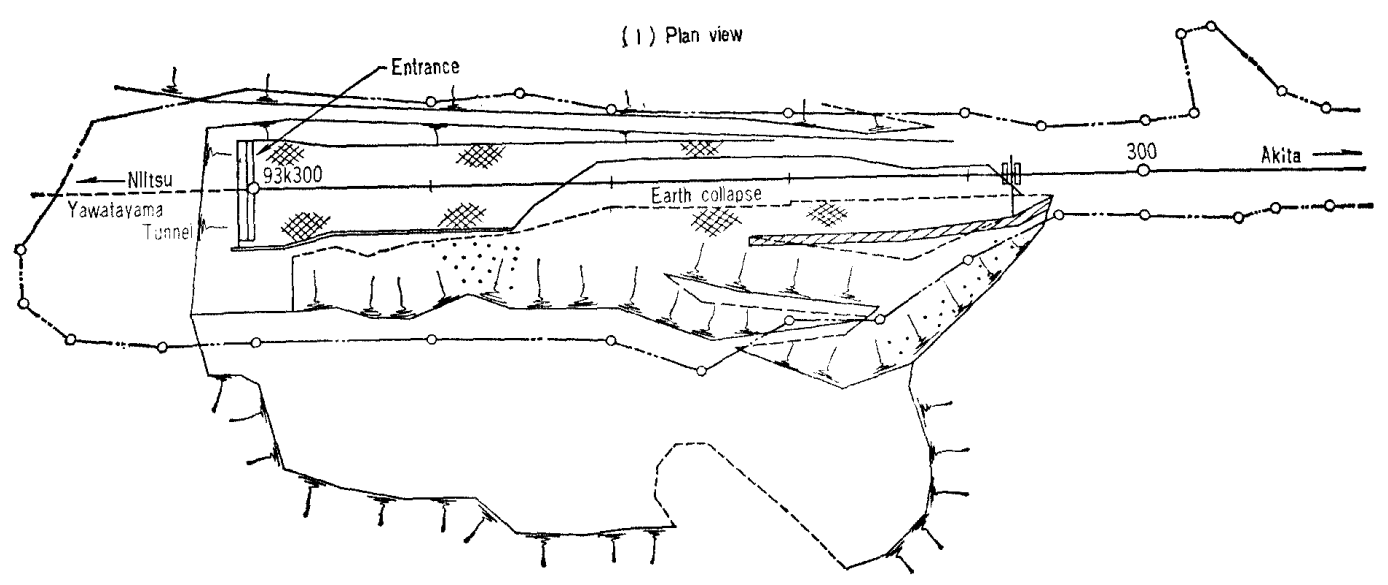

(1) Plan view:

(2) Cross section

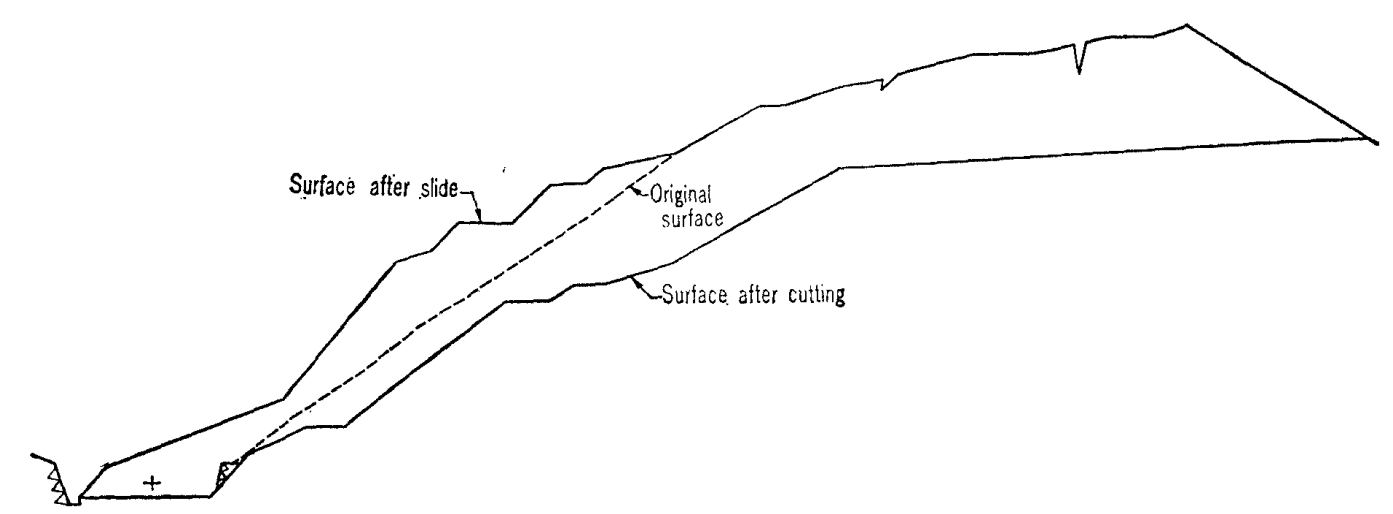

(2) Cross section

Fig. 6. Cross section Small land slide near the entrance of Yawatayama tunnel at Uetsu-Line

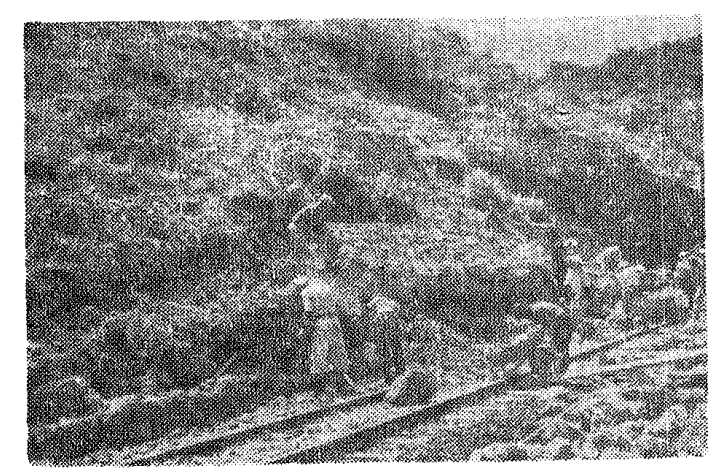

Photo. 5. Slope failure near the entrance of Yawatayama Tunnel at Uetsu Line

A slope failure of relatively large scale occurred in the neighbourhood of the entrance of Yawatayama tunnel, Uetsu-Line. Fig. 6 and Photo. 5 show the slope failure. A volume of the failed mass was about $2,000 \mathrm{~m}^{3}$. This slope was constructed by cutting 
and the toe of slope was protected by masonry wall having about 8 meters height. Geology of this slope consists of deeply weathered mudstone and soft clayey soil. A successive slope failure due to aftershock and rainfall occurred on June 20. The volume of slided earthmass increased to $3,000 \mathrm{~m}^{3}$ and three fissures parallel to slope also occurred. This unstable earthmass was removed and a grade of slope was flattened to obtain tsable state.

The restoration work in this section took the longest time among those of damage in main lines.

\section{(4) Deformation of tunnel}

No serious damage to tunnel occurred all along a line. It may be true that in general, lining of tunnel is stable against an earthquake under a good geological condition. A lining of tunnel under a good geological condition and good construction could have a sufficient resistance against earthquake force because a displacement due to earthquake decreases in proportion to depth. However, tunnels located at inadequate site suffered by the earthquake.

At Terasaka Tunnel of Uetsu-Line, longitudial cracks of lining occurred at side wall and arch. Some parts of crown was crushed by compressive force. This tunnel had been built in a slope having landslide topography and it had been difficult to construct the lining against strong earth pressure. It is recognized that these cracks had

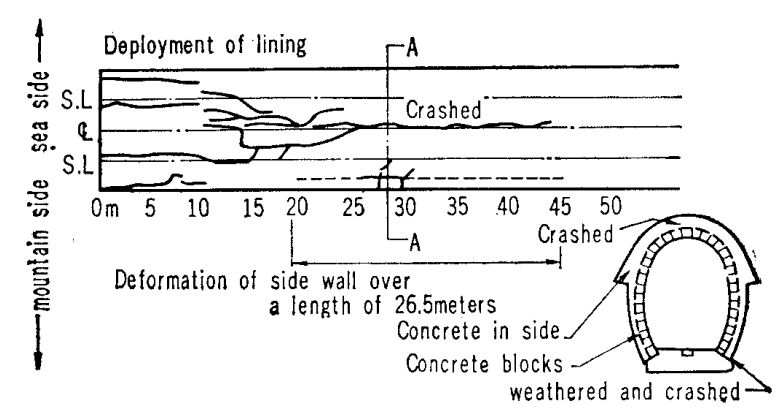

Fig. 7. Cracks and deformation of lining of Terasaka-tunnel in Uetsu-Line

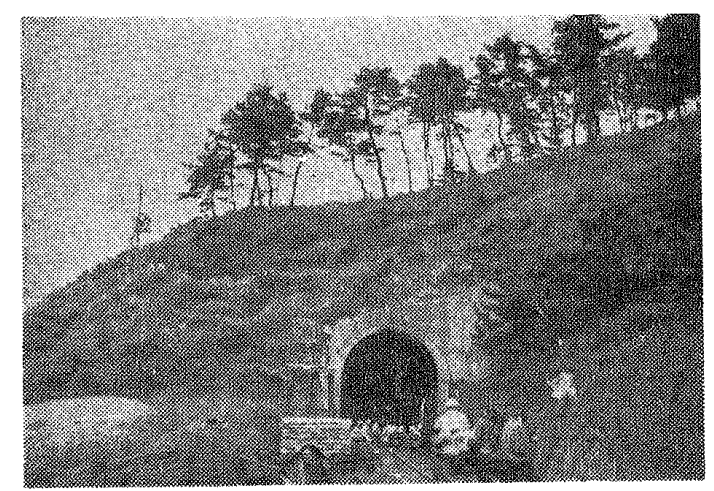

Photo. 6. Topography near the entrance of Terasaka Tunnel. 
already occurred during construction and were enlarged by the earthquake.

A lining of tunnel could not resist to the lateral earth pressure under insufficient overburden load.

Fig. 7 shows the sketch of cracks and deformation of lining. Photo. 6 shows topography near the tunnel.

(5) Rotation of pier and movement of abutment

Rotation of pier and movement of abutment occurred widely at a severely damaged area as previously mentioned. There are several one-span overbridges between Sekiya St. and Hakusan St., and all of them were more or less damaged. These damage are due to the liquefaction of soft ground as previously mentioned in fill failure.

Photos. 7, 8, 9 show movement of abutment and slumping of approach fill. The foundation of abutment is wooden piles of 7 meters length. Approach fill of abutment slumped down by about 3 meters and masonry wing wall tilted remarkably backward or collapsed. Both abutments moved towards each other and resulted in upheaval of pavement between them.

Rotation of bridge pier with well foundation occurred at Shinano Bridge at Echigo Line. This bridge is composed of 15 plategirders and 14 piers with well foundation.

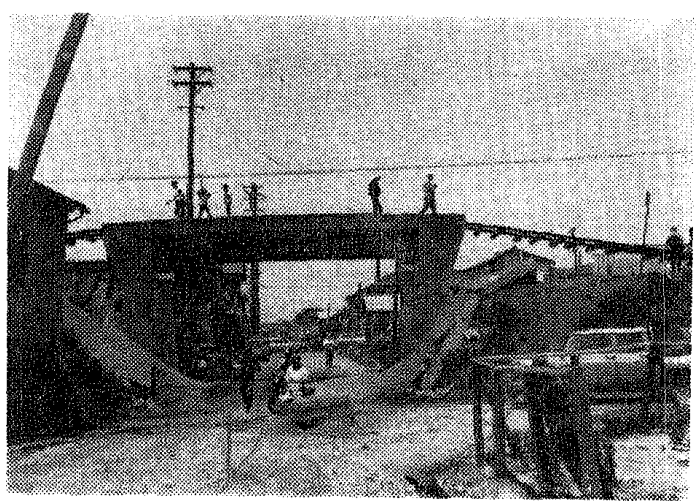

Photo. 7. Slumped approach fill (Teramae-Bridge)

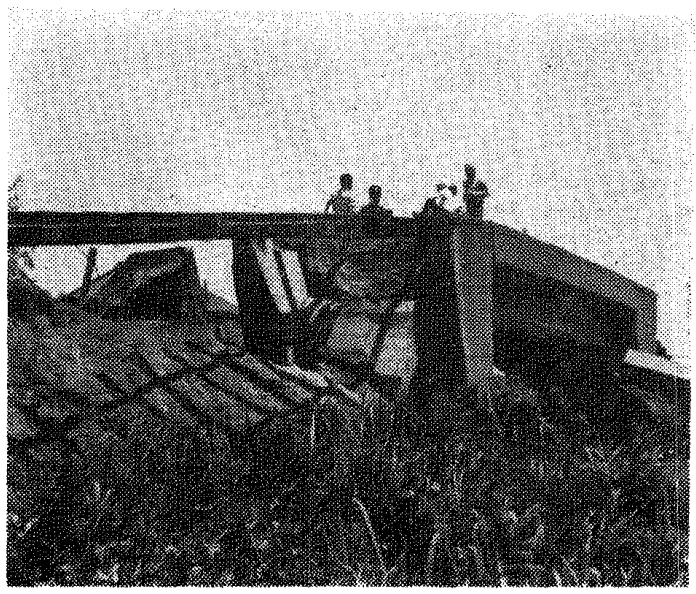

Photo. 8. Collapsed approach fill (Teramae Bridge) 


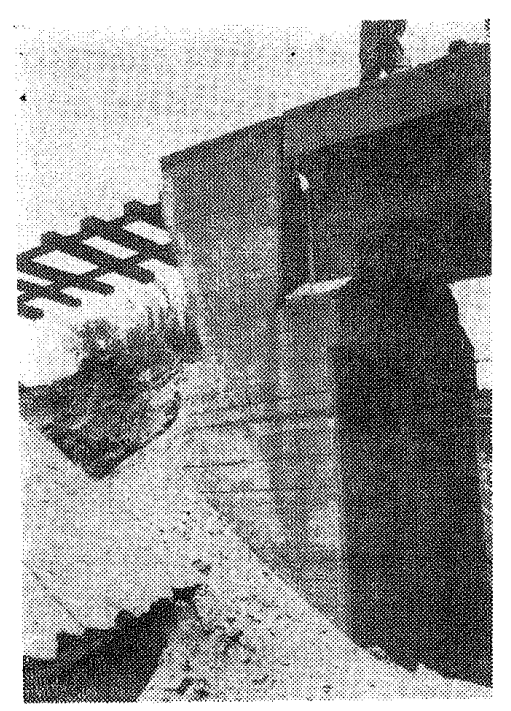

Photo. 9. Collapsed wing wall (Teramae Bridge)

The length of well at both end piers (pier No. 1 and pier No. 14) is 10 meters while the others are 18 meters. The left side bank moved towards midstream and the rotation of No. 1 pier and movement of abutment No. 1 occurred. The other piers and abutment were not so severely affected that there was no difficulty in reopening traffic without reconstruction.

The site of pier No. 1 had been riverbed about 3 meters of water depth at the time of construction and had been filled up to the road during construction. Shortening of well No. 1 is due to the above mentioned reasons. An amount of displacement at the top of pier No. 1 is 1.8 meters towards midstream and 0.5 meters towards upstream and inclination of pier is about 8 degree as shown in Fig. 8 and Photo. 10.

An inspection by test pit shows that both pier and well have no fractures and cracks. It is supposed that the pier and well rotated as one body and the centre of rotation may be the lowest right end of the well.

The soil profile of Fig. 9 indicates the subsurface condition near pier No. 1. Soil formatin up to 10 meters depth consists of loose saturated sand and its $\mathrm{N}$ values are less than 10 .

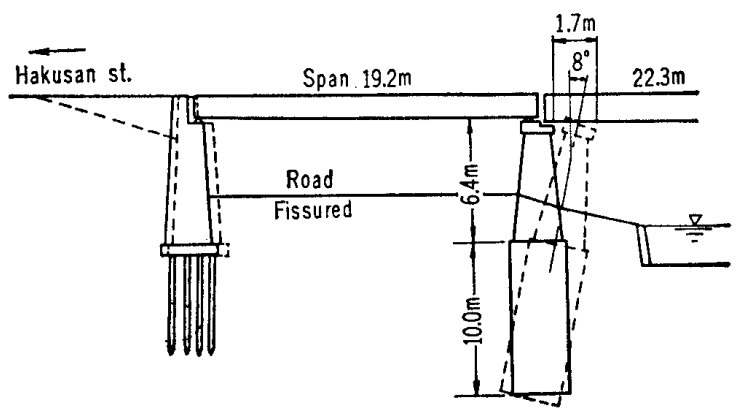

Fig. 8. Rotation of No. 1 pier of Shinanogawa Bridge in Echigo-Line 


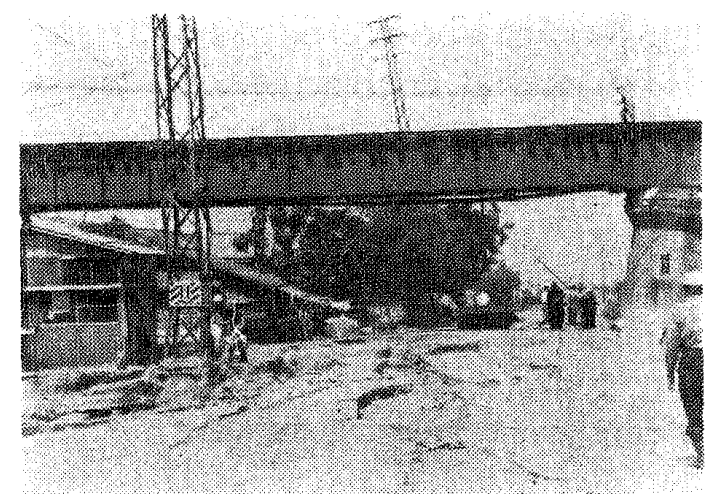

Photo. 10. Rotation of No. 1 Pier of Shinanogawa Bridge in Echigo Line

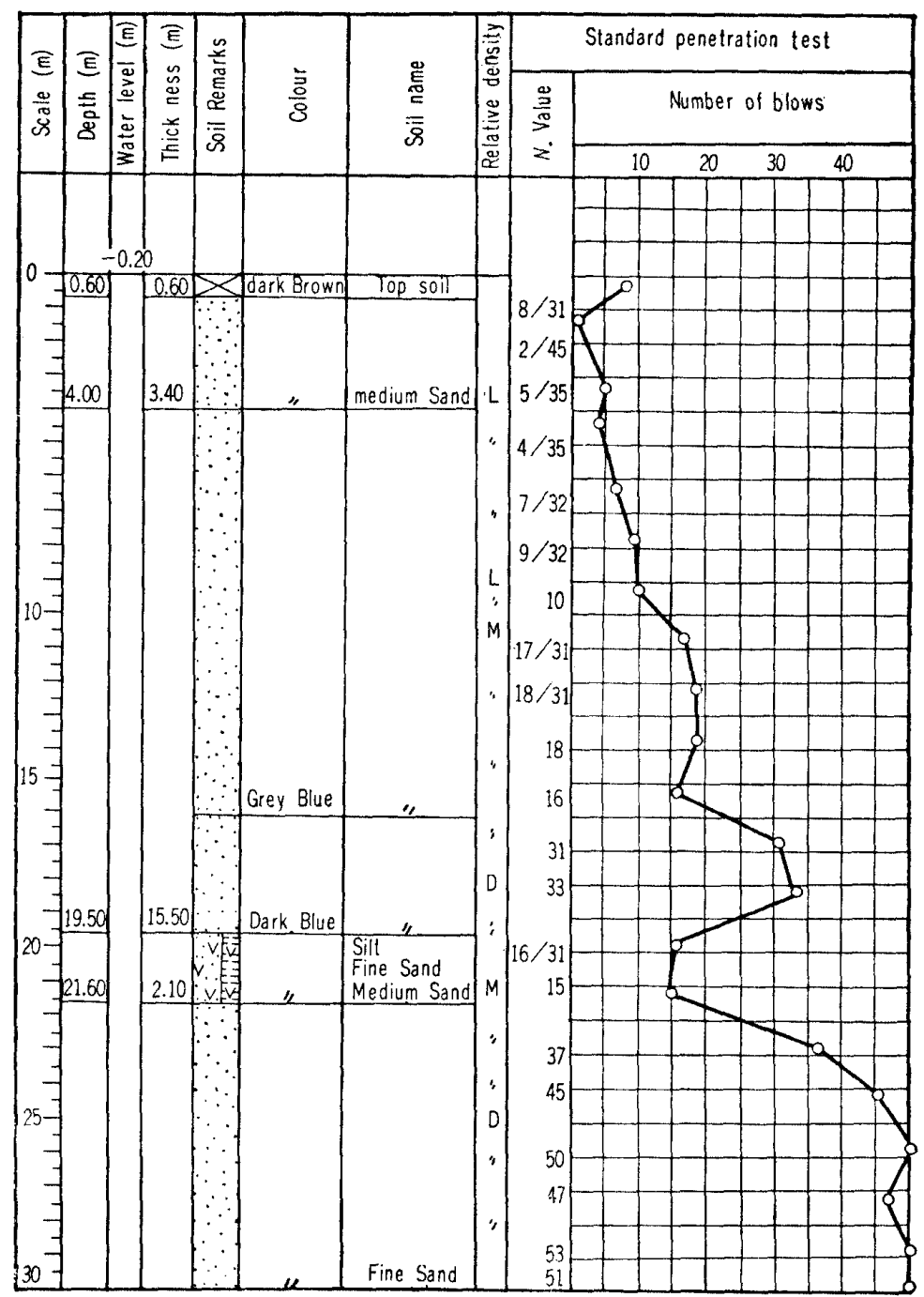

Fig. 9. Soil profile near No. 1 pier of Shinanogawa Bridge 
The cause of rotation of pier may be explained by the strong lateral earth pressure due to the ground displacement and liquefaction of loose saturated sand.

\section{CONCLUSION}

Much damage of earth-structure and foundation was resulted by the liquefaction of saturated loose sand. A detailed study for mechanism of liquefaction and more precise investigation of subsurface condition should be necessary in order to obtain a proper design method for foundation and to prevent a collapse of artificial fill.

However, it should be emphasized that there were a good foundation design which

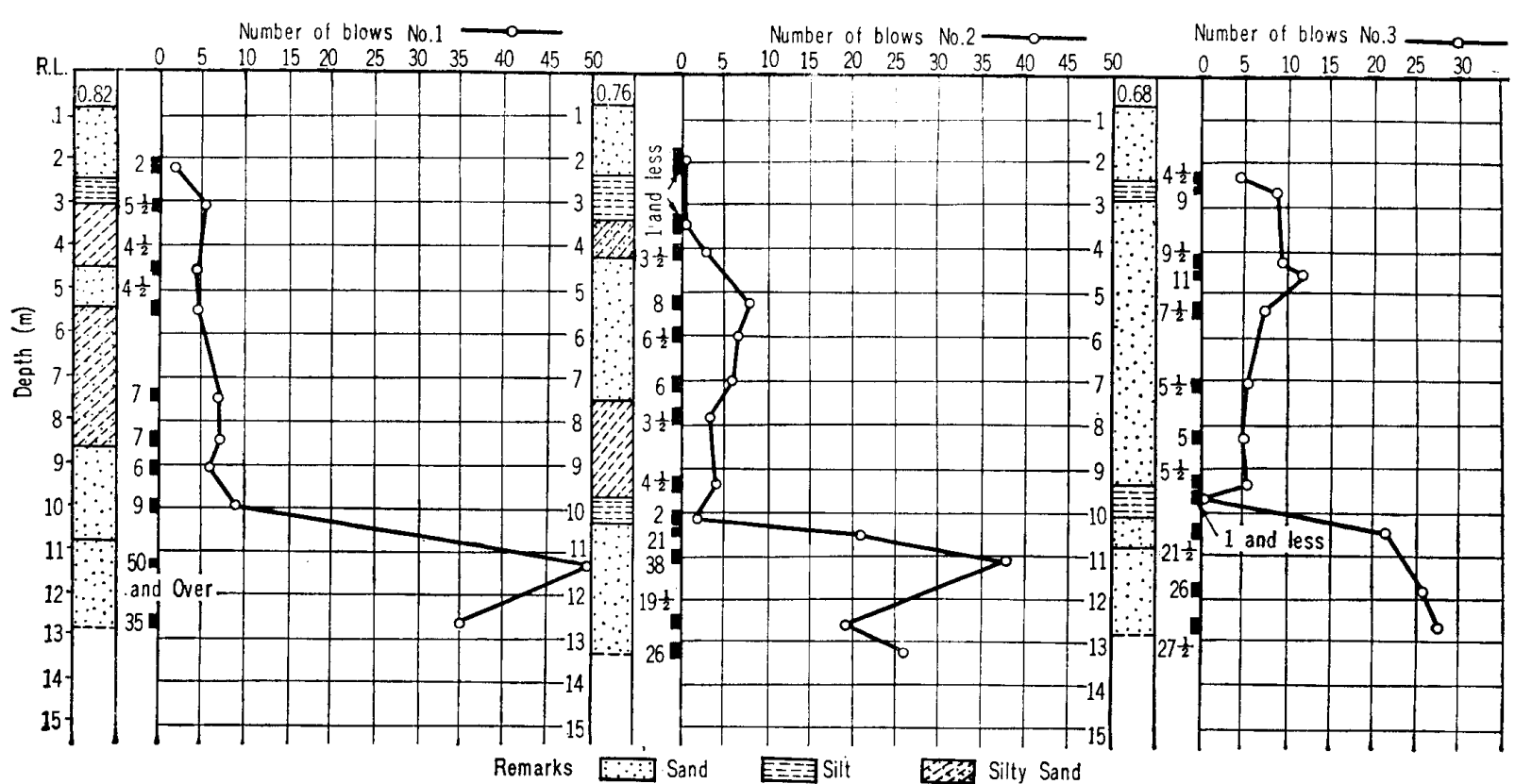

Fig. 10. Soil profile at the site of Niigata Station Building

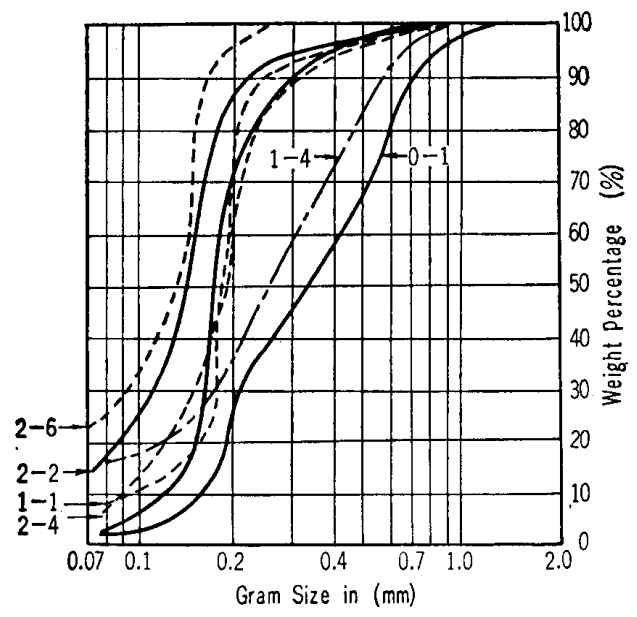

Fig. 11. Grain size distribution curves of sand 
had mitigated the effect of the ground-motion accompanied by the liquefaction of sand. This example was a building foundation of Niigata Station Building which had been consturcted in 1954.

Precise borings including standard penetration test, undisturbed sampling of loose sand below water table, load test at the abutment of foundation and laboratory test including determination of critical void ratio had been performed.

Representative soil profile obtained by the boring is shown in Fig. 10 and grain size distribution of sand in Fig. 11.

Soil formation up to 12 meters depth below surface consists of loose saturated sand having $N$ value less than 10 . The void ratio in situ is in a range from 0.87 to 0.9 and the critical void ratio obtained by shear test is between 0.85 to 0.90 . Both values show a good coincidence with each other.

It was reasonable to conclude that the liquefaction of loose sand due to earthquake would occur and preventive measures against liquefaction should be necessary.

Foundation of the building under the first basement was surported by wooden piles

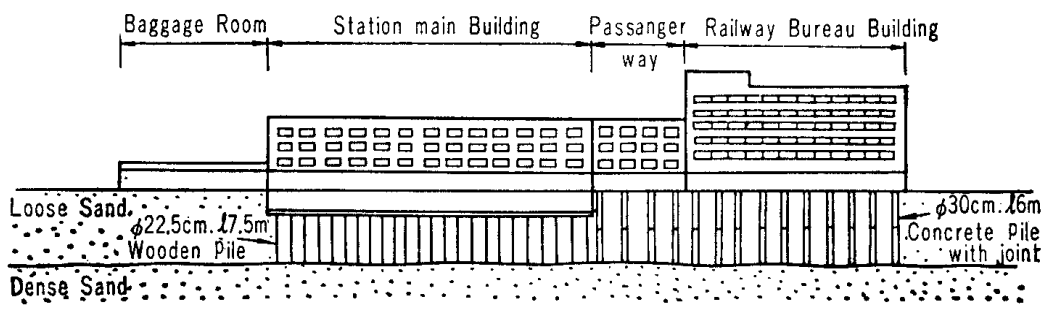

Fig. 12. Niigata Station Building

having 7.5 meters length and $22.5 \mathrm{~cm}$ diameter, penetrating into soft ground down to the firm stratum as shown in Fig. 12.

A four-storied building which had been constructed under these considerations suffered no damage due to liquefaction while neighbouring buildings without pile foundation suffered severe unequal settlement or tipping.

The Niigata Earthquake was so instructive that damage to foundation and structure had close relation with subsoil condition and much damage was produced by liquefaction of loose sand. Precise investigation of soil in situ and a detailed study of soil properties should be necessary for good foundation design to prevent such damage.

\section{ACKNOWLEDGEMENT}

This report was summarized from "Report of Survey of the Niigata Earthquake. No. 448, Nov., 1964." published by the Railway Technical Research Institute, Japan National Railways, and Field Report by Civil Engineering Division, JNR. 